\title{
Prevalence and factors associated with violence and abuse of older adults in Mexico's 2012 National Health and Nutrition Survey
}

Maria Guadalupe Ruelas-González , María Beatriz Duarte-Gómez ${ }^{1 *}$, Sergio Flores-Hernández', Doris Veronica Ortega-Altamirano ${ }^{1}$, Jesus David Cortés-Gill, Arianna Taboada ${ }^{3}$ and Ana Lorena Ruano ${ }^{2}$

\begin{abstract}
Background: Factors associated with violence and the abuse of older adults are understudied and its prevalence in Mexico has not been reported. The aim of this study was to identify the prevalence and factors associated with violence and abuse of older adults in Mexico.

Methods: We used Mexico's 2012 National Health and Nutrition Survey, which included a sample of 8,894 individuals who are 60 years or older and who self-reported a negative health event related to robbery, aggression or violence in the previous 12 months. We used chi-squared test and Fisher's exact test to analyze the variables related to violence. Adjusted estimates were completed with multiple logistic regression models for complex surveys.

Results: The prevalence of violence was $1.7 \%$ for both men and women. In $95 \%$ of the cases, the aggression was from an unknown party. Verbal aggressions were the most prevalent (60\%). Among men, physical aggression was more common. Violence frequently occurred in the home (37.6\%); however, men were primarily assaulted in public places (42.4\%), in comparison to women (30.7\%). There were also differences in the risk factors for violence. Among men, risk was associated with younger age (60-64 years), higher education (secondary school or above) and higher socioeconomic status. Among women, risk was associated with depression, not being the head of the family, and region of the country.

Conclusions: Violence against older adults presents differently for men and women, which means it is necessary to increase knowledge about the dynamics of the social determinants of violence, particularly in regards to the role of education among men. The relatively low prevalence found in this study may reflect the difficulty and fear of discussing the topic of violence. This may occur because of cultural factors, as well as by the perception of helplessness perpetuated by the scarce access to social programs that ensure protection and problem solving with regards to the complex social determinants of individual and family violence that this population group endures.
\end{abstract}

Keywords: Abuse, Violence, Older adults, Aging, Mexico

\footnotetext{
*Correspondence: beatriz.duarte@insp.mx

${ }^{1}$ Instituo Nacional de Salud Pública, Cuernavaca, México

Full list of author information is available at the end of the article
} 


\begin{abstract}
o
Antecedentes: Los factores asociados con la violencia y el abuso de los adultos mayores están poco estudiados y su prevalencia en México no ha sido reportada. El objetivo de este estudio fue identificar la prevalencia y los factores asociados a la violencia y el abuso de los adultos mayores en México.

Metodología: Se utilizó la Encuesta Nacional de Salud y Nutrición 2012. La muestra estuvo conformada por 8,894 personas de 60 años de edad o mayores que autoreportaron haber sufrido algún daño a la salud por robo, agresión o violencia en los últimos 12 meses. Se efectuó un análisis de factores asociados con la violencia con las pruebas ji cuadrada y la exacta de Fisher; se obtuvieron estimaciones ajustadas con modelos de regresión logística múltiple para encuestas complejas.

Resultados: La prevalencia de violencia fue de $1.7 \%$ para ambos sexos. En el 95 \% de los casos, la agresión provino de personas sin vínculo filial. Predominaron las agresiones verbales (60\%), aunque entre los hombres fueron más comunes las agresiones físicas. La violencia se produjo con mayor frecuencia en el hogar (37.6\%); sin embargo, los hombres fueron agredidos principalmente en la vía pública (42.4\%), comparado con las mujeres (30.7 \%). También hubo diferencias en los factores de riesgo para sufrir violencia: en hombres se asocia con menor edad (60 a 64 años), mayor escolaridad (secundaria o más) y mayor nivel socioeconómico; en las mujeres, con tener depresión, no ser jefe de familia y la región del país.

Conclusiones: La violencia contra las personas mayores se presenta de manera diferencial entre hombres y mujeres. Es necesario profundizar en los determinantes sociales de la violencia, en particular en el papel de la escolaridad entre los varones. La prevalencia relativamente baja, en comparación con otros estudios, puede obedecer a la dificultad y al temor para hablar sobre este tema tanto por razones culturales, como por la indefensión frente al escaso acceso a programas sociales que den protección y solución y que incidan sobre los determinantes sociales asociados a la violencia familiar y social que sufre este grupo poblacional.
\end{abstract}

Palabras clave: Maltrato, Violencia, Personas mayores, México

\section{Background}

Violence and abuse have harmful effects on the health and wellbeing of individuals, families, communities and countries [1]. The contribution of violence to the mortality and morbidity burden demands an increased investment of economic, social, and human resources, as well as a redefining of health priorities. The World Health Organization [2] defines violence as the intentional use of power, whether this comes in the shape of a threat or action against oneself, another person or a group, or community which leads to a high likelihood of injury, death or deprivation. When it comes to older adults, this can take place at the community level, when it is defined as violence, or be carried out by family or caretakers that reside within the home, where it is known as abuse $[3,4]$

Current epidemiologic and demographic shifts have contributed to increasing the population of older adults, and this trend is expected to almost double from 9.7 in 2014 to $21.5 \%$ by 2050 [5]. The decrease of family support options, which is a product of the changes in family structure and composition, are combined with the socioeconomic and health conditions that older adults may live with as well as changes in cultural values related to age. These act as determinants of violence and abuse towards older adults. Some international studies report that there is an association between these determinants and the deteriorating health status of older adults, which may include depression, advanced age, gender (female), higher education, low SES, social isolation, history of family violence, codependency with the aggressor, and characteristics of the primary care giver and their level of exhaustion [4, 6-8].

Studies about the prevalence of violence and abuse of older adults, are scarce and variable. In a systematic review of the prevalence of abuse in various countries, authors reported a wide variability of prevalence, from 3.2 to $27.5 \%$. This can be explained by the diversity of definitions, typologies, methodologies and instruments used $[9,10]$. In a study conducted in Latin America, authors found that lifetime experience of physical violence towards older adults perpetrated by the spouse, was more frequent among women as compared to men, with a prevalence rate between 1.6 and $2.1 \%[4,11]$.

In Mexico, a study of four states found $16 \%$ prevalence of abuse towards older adults, based on selfreported data [12]. Moreover, the National Family Life Survey, 2011, [13] reported the following prevalence for type of abuse for female older adults: $13.4 \%$ emotional, $10.8 \%$ neglect and $1 \%$ physical abuse. In order to make the problem more visible and generate policies and interventions that can decrease violence towards this 
population, it is critical to understand the magnitude of the problem and the associated factors $[7,14,15]$. With respect to mortality due to violence among older adults, in 2013 it caused $4.2 \%$ of all deaths among all older adults. This rate rose to $5.6 \%$ among the 60-64 age group and was found predominantly among men $(8.1 \%)[3,16]$. The objective of the present study was to estimate the prevalence of violence towards older adults, as well as the associated factors, using data from Mexico's 2012 National Health and Nutrition Survey, NHNS (ENSANUT in Spanish) [17].

\section{Methods}

We conducted a secondary data analysis using data from Mexico's 2012 NHNS, which is a probabilistic survey with multistage and stratified sampling that allows for a representative sample of the population at the state and national level, as well as by urban and rural strata. The sample comprised of 8,894 adults who are 60 years of age or older. Due to the expanding factor calculated in the NHNS design, this sample is representative of $10,747,490$ older adults. The response rate for completed surveys was $87 \%$ [18].

Surveyors asked the older adults about episodes of violence such as being the victim of robbery, aggression, assault, abuse or other types of violence in the last 12 months. For the positive responses to these questions, an initial analysis was conducted to describe the variables of violence (by unknown party) and abuse (by member of the family). However, given the low frequency of older adults who reported abuse and the difficulty conducting a rigorous statistical analysis, we decided to group the two variables together, creating the dependent variable (binary) labeled "violence/ abuse". The independent variables included in analysis were: age, sex, living with five or more people in the same house, head of household's condition, education, having a partner, diagnosed with a non-communicable chronic disease (diabetes, hypertension, cardiovascular disease, other heart disease, or cancer), being diagnosed with depression by a health professional, having limited function (at least one limitation to daily activities such as walking, bathing, lying down/standing up, getting dressed or having a limitation in instrumental daily activities such as preparing food, buying food, taking medication, or managing money), cognitive deterioration (being unable to draw a clock, remembering 1 or 2 , or no words), low self-esteem (self-classification as valuable individuals or not) and loss of power within the family (not consulted for important decisions or household finances or no contribution to household income). We also used region and socioeconomic status (SES) as an independent variable, and used the NHNS household and SES classification described by Gutiérrez and colleagues in 2013 [19] in line with the income deciles previously defined in the database, which corresponded to low (deciles 1 and 2), medium (deciles 3 to 6) and high (deciles 7 to 10). Finally, the country was divided into four geographic regions: North, Central-Western, Central and South-Southeast

We conducted a descriptive analysis of the variables with confidence intervals of $95 \%$. Considering the sampling strategy utilized for the survey permitted unbiased estimates. To calculate the variance, we used the mean total score for strata with a single sampling unit. The sample size varied based on the analysis variable. For the analysis of the variables of most interest with the population of older adults, using both men and women, we utilized the STATA command "subpop" (subpopulation).

We also evaluated the association of independent variables with the violence/abuse variable by using the chisquared test or Fisher's exact test, and crude odds ratios in the bivariate analysis. Finally, we used multiple logistic regression models to find adjusted estimates. This was done because of the complex survey design used for the NHNS; one for men and another for women. All statistical analysis was performed using STATA version 13.0 [20].

\section{Results}

We analyzed data from 8,894 older adults $(4,042$ men and 4,852 women) with a mean age of 70.6 years. The prevalence of violence found was $1.7 \%$ (CI $95 \% 1.2 \%$ to $2.2 \%$ ) [ $n=119, N=184,757]$, with no statistically significant different between men $1.7 \%$ (CI $95 \% 1.1$ to 2.6) and women $1.7 \%$ (CI $95 \% 1.0$ to 2.7).

Of the sample, a 119 older adults, $95.7 \%$ (CI $95 \%$ 91.7 to 99.6$)$, reported experiencing violence, with a significantly greater proportion $(p<0.05)$ among men 99.4 \% (CI $95 \% 97.4$ to $99.9 \%$ ), than among women $92.6 \%$ (CI $95 \% 81.3$ to $97.3 \%$ ). Moreover, $4.3 \%$ (CI $95 \% 0.4$ to 8.3 ) of the older adults reported to have been subjected to abuse, with a greater proportion among women $7.4 \%$ (CI $95 \% 2.7$ to $18.7 \%$ ) than among men $0.6 \%$ (CI $95 \% 0.1$ to $2.6 \%$ ).

In the violence/abuse category there were statistically significant differences between men and women by type of aggression (Table 1). In general, verbal aggressions dominated (62.9\%), followed by physical aggression in the form of "hitting, kicking, and punching" among men (32.3\%), and "other types of aggression or abuse" among women $(18.7 \%)$.

With regards to where violence/abuse occurred, $37.6 \%$ (CI $95 \% 26.3$ to 50.4) took place in the home, followed by $31.5 \%$ (CI $95 \% 20.3$ to 45.3 ) of instances that took place in public spaces. The findings indicate that women experienced aggression or violence with greater frequency within the home at $40.0 \%$ (CI $95 \%$ 
Table 1 Violence/abuse, prevalence of types of aggression among older adults, by sex. Mexico's 2012, National Health and Nutrition Survey

\begin{tabular}{|c|c|c|c|}
\hline & Men & Women & All \\
\hline & $n=55$ & $n=64$ & $n=119$ \\
\hline Type of aggression & $\%(C \mid 95 \%)$ & $\%(C l 95 \%)$ & $\%(C \mid 95 \%)$ \\
\hline Verbal aggressions & $61.2(41.9-78.2)$ & $64.3(44.1-88.4)$ & $62.9(48.7-75.1)$ \\
\hline Hitting, kicking, punching & $32.3(16.4-56.7)$ & $9.8(4.3-20.6)$ & $20.1(11.7-32.3)^{*}$ \\
\hline Other aggressions or abuse & $1.2(0.3-4.6)$ & $18.7(7.4-39.8)$ & $10.6(4.4-23.4)^{*}$ \\
\hline Other & $18.3(8.3-35.7)$ & $8.5(3.8-17.7)$ & $13.0(7.4-21.9)$ \\
\hline Pushing downward from an elevated location & $1.8(0.3-9.2)$ & $2.1(0.6-7.7)$ & $2.0(0.7-5.3)$ \\
\hline Aggressions with substances & $2.0(0.3-13.4)$ & $0.0-$ & $0.9(0.1-6.4)$ \\
\hline Suffocation, strangulation, drowning & $1.5(0.2-10.1)$ & $0.3(0.004-2.4)$ & $0.9(0.2-4.3)$ \\
\hline Sharp object wound (knife, blade, etc.) & $0.1(0.008-1.0)$ & $1.4(0.2-9.2)$ & $0.8(0.1-4.8)$ \\
\hline Sexual assault & - & $1.5(0.3-7.2)$ & $0.8(0.2-3.9)$ \\
\hline $\begin{array}{l}\text { Poisoning or airway obstruction with } \\
\text { substances or hot objects }\end{array}$ & - & - & \\
\hline Firearm wound & - & - & - \\
\hline $\mathrm{NA} / \mathrm{DK}^{\mathrm{a}}$ & $1.0(0.2-7.0)$ & $1.3(0.2-8.9)$ & $1.2(0.3-4.7)$ \\
\hline
\end{tabular}

${ }^{*} p<0.05$

${ }^{a}$ NA/DK means Not answered/Don't know

26.0 to 55.7), compared to men at $34.7 \%$ (CI $95 \%$ 18.0 to 56.2). In the case of the men, they experienced greater aggression in public places at $42.4 \%$ (CI $95 \%$ 17.1 to 52.7 ) than women at $30.7 \%$ (CI $95 \% 16.2$ to 50.3) (Graph 1).

Regarding the care received by older adults following an aggression, $61.5 \%$ (CI $95 \% 48.0$ to 75.4 ) were cared for by a family member, friend or neighbor, $26.1 \%$ (CI $95 \% 14.7$ to 37.6 ) saw a chiropractor and only $0.6 \%$ (CI $95 \%-0.6$ to 1.7 ) were seen by a medical professional.

In the bivariate analysis for men (Table 2), the factors associated with violence/abuse were age, education, and SES. Nearly $60 \%$ of the older adults between 60 and 65 years of age were the victims of violence/abuse and were five times as likely to be victims (OR 5.7, CI $95 \%$ 1.8 to 17.8 ) when compared to men 75 years or older. Over $50 \%$ of those who had experienced violence/abuse

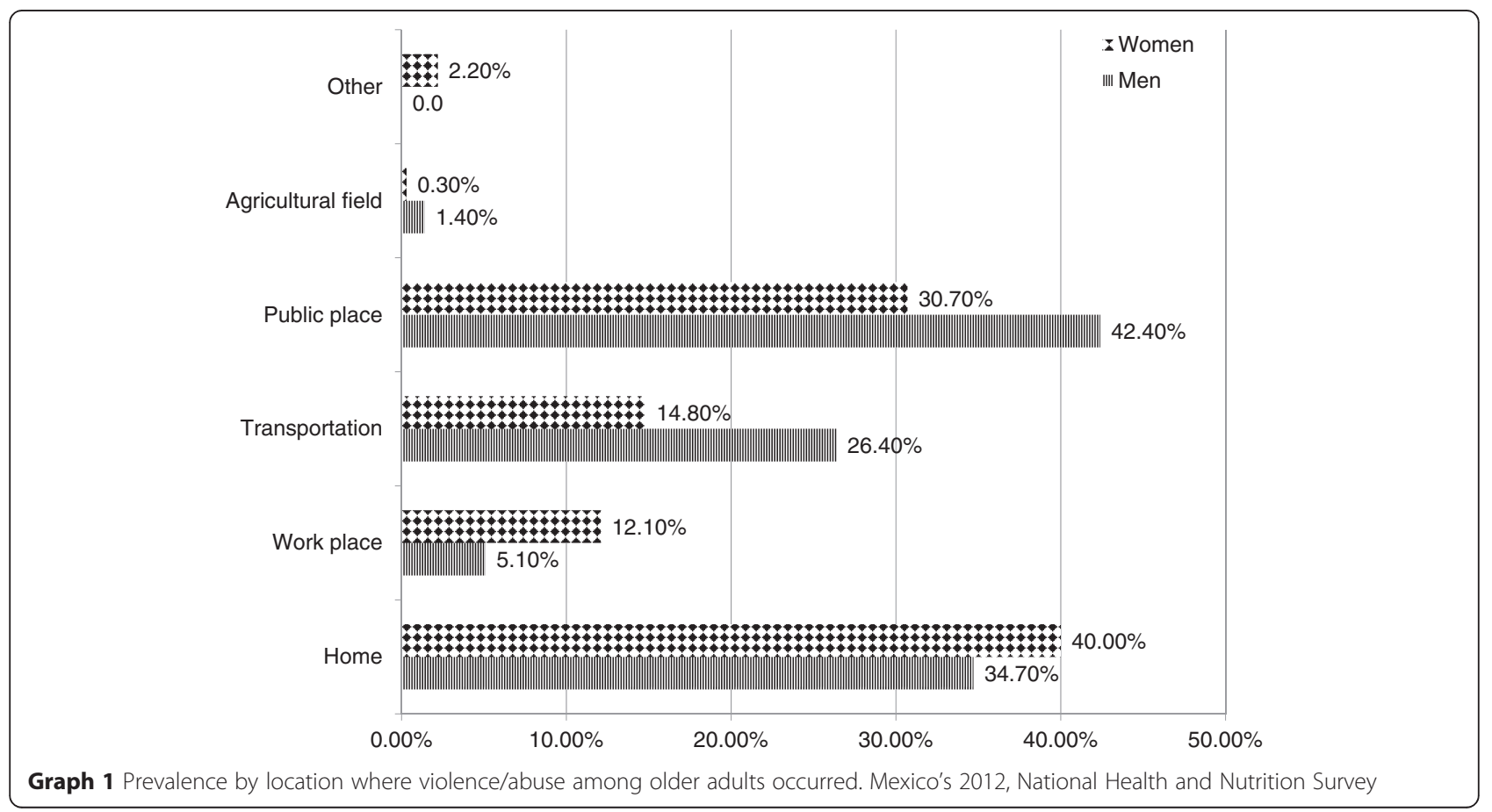


Table 2 Factors associated with the presence of violence abuse among older adult males. Mexico's 2012, National Health and Nutrition Survey

\begin{tabular}{|c|c|c|c|c|}
\hline \multicolumn{5}{|l|}{ Violence/abuse $n=4,042$} \\
\hline & No $(n=3,987)$ & Yes $(n=55)$ & & \\
\hline & $\%(C l 95 \%)$ & $\%(C l 95 \%)$ & OR (Cl 95 \%) & $P$-value \\
\hline \multicolumn{5}{|l|}{ Age } \\
\hline$<65$ years & $29.4(27.1-31.8)$ & $58.1(37.8-76.0)$ & $5.7(1.8-17.8)$ & 0.003 \\
\hline $65-74$ years & $41.8(39.2-44.5)$ & $31.8(16.5-50.5)$ & $2.2(0.8-6.1)$ & 0.13 \\
\hline $75+$ years & $28.8(26.3-31-4)$ & $10.0(3.8-23.8)$ & 1.0 & \\
\hline Lives with $5+$ people & $34.6(32.1-37.1)$ & $35.5(19.4-55.6)$ & $1.0(0.4-2.4)$ & 0.92 \\
\hline Is not the head of the household & $12.8(11.1-14.7)$ & $8.8(2.9-24.1)$ & $0.7(0.2-2.2)$ & 0.49 \\
\hline \multicolumn{5}{|l|}{ Education } \\
\hline Secondary+ & $23.9(21.1-26.8)$ & $53.3(32.6-73.0)$ & $3.6(1.5-8.7)$ & 0.003 \\
\hline Has partner & $76.2(74.0-78.2)$ & $84.8(69.5-93.2)$ & $1.7(0.7-4.3)$ & 0.23 \\
\hline \multicolumn{5}{|l|}{ Region } \\
\hline North & $19.2(17.4-21.1)$ & $19.5(9.2-36.7)$ & 1.0 & \\
\hline North-west & $24.5(22.3-26.9)$ & $20.4(9.9-37.5)$ & $0.8(0.3-2.2)$ & 0.69 \\
\hline Central & $31.9(28.9-35.1)$ & $40.0(19.2-65.1)$ & $1.2(0.4-4.1)$ & 0.73 \\
\hline South-southeast & $24.4(22.4-26.6)$ & $20.2(9.2-38.7)$ & $0.8(0.3(2.2)$ & 0.69 \\
\hline \multicolumn{5}{|l|}{ SES } \\
\hline Low & $25.2(23.2-27.4)$ & $16.6(7.7-32.2)$ & 1.0 & \\
\hline Medium & $37.1(34.6-39.8)$ & $21.2(10.6-38.1)$ & $1.2(0.5-2.9)$ & 0.76 \\
\hline High & $37.7(35.1-40.3)$ & $62.1(42.2-78.7)$ & $2.9(1.1-7.3)$ & 0.03 \\
\hline Chronic disease & $48.0(45.5-50.6)$ & $56.5(34.0-76.6)$ & $1.4(0.6-3.6)$ & 0.47 \\
\hline Depression & $7.2(5.6-9.2)$ & $10.4(2.2-37.9)$ & $1.5(0.3-8.1)$ & 0.64 \\
\hline Functional dependence & $44.1(41.4-47.0)$ & $25.9(13.4-44.0)$ & $0.4(0.2-1.0)$ & 0.05 \\
\hline Cognitive deterioration & $18.6(16.6-20.7)$ & $18.3(8.1-36.4)$ & $1.0(0.4-2.5)$ & 0.98 \\
\hline Low self esteem & $9.6(8.1-11.3)$ & 0.0 & 1.0 & 0.20 \\
\hline Dissatisfaction with life & $2.7(2.0-4.0)$ & $2.7(0.4-14.7)$ & $1.0(0.2-6.4)$ & 0.98 \\
\hline Loss of power in the home & $9.6(7.9-11.7)$ & $6.0(1.8-17.8)$ & $0.6(0.2-2.1)$ & 0.42 \\
\hline No economic contribution & $9.5(7.9-11.4)$ & $6.9(2.3-18.9)$ & $0.7(0.2-2.2)$ & 0.55 \\
\hline
\end{tabular}

has finished at least secondary school and were 2.6 times as likely to be victims (OR 3.6,CI $95 \% 1.5$ a 8.7), compared to men with less education. Lastly, $62.1 \%$ of men who reported violence/abuse belonged to a high SES, with twice the likelihood of being a victim (OR 2.9, CI $95 \% 1.1$ a 7.3), compared to men with low SES. In the bivariate analysis for women (Table 3 ) nearly $42 \%$ of the women who reported violence/abuse also reported depression and were three times as likely to be victims (OR 3.3, CI $95 \% 1.5$ a 7.0). The variables related to other diagnoses among older adults were not found to be statistically significant.

In the multiple regression models (Table 4), the factors associated with violence/abuse (adjusted OR) were different for men than for women. For men, age was the most important factor, with nearly four times the likelihood of suffering violence/abuse in the 60-65 years-of-age range and the highest education. In women, depression increased the likelihood of experiencing violence/abuse by 3.4 times, more so than other factors such as not being the head of the household or region of the country. The North region serves as a reference, while women in the Central region of the country had greater likelihood of undergoing violence/abuse, and women in the South-Southeast and Northwest, less.

\section{Discussion}

This study represents a contribution to the identification of the magnitude of violence and abuse experienced by older adults at the national level, especially taking into account that the extant literature is often restricted to the regional or local level, or to specific cases or violence in the home $[4,11,21,22]$. In contrast, our data set 
Table 3 Factors associated with the presence of violence abuse among older adult females. Mexico's 2012, National Health and Nutrition Survey

\begin{tabular}{|c|c|c|c|c|}
\hline \multicolumn{5}{|l|}{ Violence/abuse $n=4,852$} \\
\hline & No $(n=4,788)$ & Yes $(n=64)$ & & \\
\hline & $\%(C \mid 95 \%)$ & $\%(C l 95 \%)$ & OR (Cl $95 \%)$ & $p$-value \\
\hline \multicolumn{5}{|l|}{ Age } \\
\hline$<65$ years & $29.9(27.7-32.2)$ & $37.7(18.8-61.3)$ & $1.8(0.6-4.7)$ & 0.26 \\
\hline $65-74$ years & $40.5(38.2-42.9)$ & $41.1(23.1-61.8)$ & $1.4(0.6-3.1)$ & 0.40 \\
\hline $75+$ years & $29.5(27.5-31.7)$ & $21.2(11.5-35.8)$ & 1.0 & \\
\hline Lives with $5+$ people & $32.5(30.2-34.9)$ & $31.9(15.1-55.4)$ & $1.0(0.4-2.6)$ & 0.95 \\
\hline Is not the head of the household & $58.0(55.7-60.3)$ & $71.0(56.1-82.5)$ & $1.8(0.9-3.4)$ & 0.09 \\
\hline \multicolumn{5}{|l|}{ Education } \\
\hline Secondary+ & $16.6(14.5-18.9)$ & $14.5(7.4-26.8)$ & $0.9(0.4-1.8)$ & 0.69 \\
\hline Has partner & $46.4(44.0-48.8)$ & $51.4(34.6-68.0)$ & $1.2(0.6-2.5)$ & 0.57 \\
\hline \multicolumn{5}{|l|}{ Region } \\
\hline North & $19.5(17.7-21.3)$ & $9.1(4.2-18.5)$ & 1.0 & \\
\hline North-west & $23.1(21.1-25.3)$ & $28.2(13.9-48.9)$ & $2.6(0.97-7.1)$ & 0.06 \\
\hline Central & $35.1(32.4-38.0)$ & $43.6(24.1-65.3)$ & $2.7(0.95-7.5)$ & 0.06 \\
\hline South-southeast & $22.3(20.3-24.4)$ & $19.1(4.2-18.5)$ & $1.8(0.6-5.3)$ & 0.25 \\
\hline \multicolumn{5}{|l|}{ SES } \\
\hline Low & $25.5(23.4-27.7)$ & $14.6(7.0-28.1)$ & $0.5(0.2-1.3)$ & 0.17 \\
\hline Medium & $41.2(38.6-43.8)$ & $45.8(27.9-64.9)$ & 1.0 & \\
\hline High & $33.3(30.8-35.9)$ & $39.6(23.2-58.7)$ & $1.1(0.5-2.5)$ & 0.88 \\
\hline Chronic disease & $60.7(58.3-63.0)$ & $59.9(41.1-76.2)$ & $1.0(0.4-2.1)$ & 0.94 \\
\hline Depression & $17.9(16.2-19.8)$ & $41.6(25.3-60.0)$ & $3.3(1.5-7.0)$ & 0.003 \\
\hline Functional dependence & $33.7(31.4-36.0)$ & $30.7(16.4-49.9)$ & $0.9(0.4-2.0)$ & 0.74 \\
\hline Cognitive deterioration & $24.6(22.6-26.7)$ & $13.7(6.7-25.9)$ & $0.2(0.2-1.1)$ & 0.08 \\
\hline Low self esteem & $7.8(6.5-9.4)$ & $7.0(2.4-18.4)$ & $0.9(0.3-2.7)$ & 0.81 \\
\hline Dissatisfaction with life & $3.1(2.3-4.1)$ & $1.2(0.2-8.3)$ & $0.4(0.05-2.9)$ & 0.35 \\
\hline Loss of power in the home & $14.3(12.7-16.0)$ & $25.8(9.7-53.1)$ & $2.1(0.6-6.9)$ & 0.23 \\
\hline No economic contribution & $36.7(34.2-39.3)$ & $21.3(9.0-42.5)$ & $0.5(0.2-1.3)$ & 0.14 \\
\hline
\end{tabular}

allowed us to look at violence at the national level. We found that violence/abuse towards older adults in Mexico can be perpetrated by both unknown and known members of the family alike, with the latter being dominant.

It is critical to pay attention to the needs of the older adult population in terms of public policy, even more when we take into account the context of social violence in most Latin American countries, and the negative changes in values towards older adults [23, 24]. In Mexico, the magnitude and dynamic of this population group presents particular characteristics. About $9.12 \%$ of the population is 60 years of age or older, and there is at least one older adult currently residing in $39 \%$ of the homes. Moreover, the population is growing faster than any other group in the country, at $3.5 \%$ annually. That is double the rate of growth of the total population of the country [5].
The dominant finding of violence perpetrated by unknown parties and the high percentage of incidents occurring outside the home (close to $60 \%$ ) and primarily among men, has implications for both social and health policy. In particular, policies must address the double effect experienced by older adults: social violence that is occurring throughout the country, and which produces fear and social isolation [25], and also violence that comes from abuse perpetrated by a family member. This multidimensionality calls for more in-depth research and analysis of what occurs in the different spaces in which older adults live their lives, so that the primary determinants of this abuse can be clearly identified and be used for designing prevention programs with an intersectoral focus.

As with other studies [23, 26-28], gender seems to be the most important determinant to describe the characteristics 
Table 4 Summary of factors associated with violence/abuse among older adults, compared by sex. Mexico's 2012, National Health and Nutrition Survey

\begin{tabular}{|c|c|c|c|}
\hline \multicolumn{2}{|l|}{ Men } & \multicolumn{2}{|l|}{ Women } \\
\hline \multicolumn{2}{|l|}{$n=4,042$} & \multicolumn{2}{|l|}{$n=4,852$} \\
\hline & $\begin{array}{l}\text { Adj. OR } \\
(\mathrm{Cl} 95 \%)^{\mathrm{a}}\end{array}$ & & $\begin{array}{l}\text { Adj. OR } \\
(\mathrm{Cl} 95 \%)^{\mathrm{b}}\end{array}$ \\
\hline$\overline{\text { Age }}$ & & $\begin{array}{l}\text { Not the head } \\
\text { of the household }\end{array}$ & $2.9(1.1-7.7)$ \\
\hline$<65$ years & $3.9(1.7-9.0)$ & Region & \\
\hline $65-74$ years & $1.6(0.6-4.5)$ & North & \\
\hline $75+$ years & 1.0 & North-west & $3.8(1.1-13.2)$ \\
\hline Education & & Central & $3.6(1.0-12.5)$ \\
\hline \multirow{2}{*}{$\begin{array}{l}\text { Secondary } \\
\text { or higher }\end{array}$} & $2.6(1.4-5.0)$ & South-southeast & $2.7(0.8-8.9)$ \\
\hline & & Depression & $3.4(1.4-8.4)$ \\
\hline
\end{tabular}

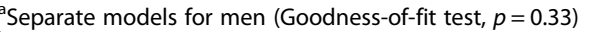

${ }^{\mathrm{b}}$ Separate models for women (Goodness-of-fit test, $p=0.06$ )

of violence/abuse in Mexico, given that the settings and types of aggression occurs in relation to the social roles traditionally assigned to men and women, respectively. Men presented more physical aggressions than women, and their abuse mostly took place outside the home at the hands of an unknown party. In turn, women experienced more psychological violence and this often occurred inside the home, perpetrated by a family member. These differences are associated with the greater presence of men in the public sphere, as well with men's traditionally higher economic independence. Finally, this abuse may also be related to risky attitudes tied to the masculine social role. In contrast, older female adults spend more time in the home, and a great percentage of them have to rely on the economic help from family members $[11,29]$.

The logistic regression models also indicate that factors associated with violence are divergent by gender. For men, the factors include lower age (60 to 64 years), supported by findings from Cuban studies demonstrating that older adults within the 60-69 age range were more likely to experience psychological and social violence, [30] and that this correlates with being more educated (secondary school or higher) and higher SES [31]. For women, the factors include having depression, not being the head of the household, and place of residence by region of the country.

Although psychological abuse was more dominant than physical abuse, the reality of one in every five older adults reporting being physically abused requires further investigation. The underreporting of this type of adverse event may be significant, given the fear or shame that may exist in reporting [15, 32, 33].

International studies found that having a partner, spending time with family, and suffering a chronic disease are all factors associated with violence and abuse
[28, 34-37]. However, these were not statistically significant findings in our study. Moreover, a factor mentioned in other studies that was not included in the NHNS was a history of family violence $[4,11,23]$. In regards to episodes of violence or abuse in which the victim sought care, they reported seeking help at home or with a chiropractor. The low utilization of health services in terms of help seeking in cases of violence identified in previous studies [38] was also a key finding for this study. This may, in part, explain the low prevalence of violence found through the health system's reporting mechanisms. It is necessary to take a more in depth look at the factors associated with the underutilization of health services following an event of violence or abuse.

Although the problem of violence among older adults has been characterized for its intersections in age, gender, and poverty, in this survey SES was not a significant factor for either men or women. In fact, men with higher education and higher SES reported great rate of violence perpetrated by unknown parties. This was an unexpected result. However, these findings are in line with others conducted among Latin American populations, and has often been explained by characteristics related to values inherent to masculinities in the region, the gender roles, and the level of empowerment fostered by education and income, which may lead to better reporting of abuse $[8,31]$. Further studies that can provide more understanding on this finding are required.

Violence is an issue of power relations among persons, and less power may lead to an increased risk for abuse. This may explain why women who were not the head of their households faced greater probabilities of being assaulted and less probability in reporting the incident [39]. This dependency may generate stress and depression, which are factors leading to increased abuse, especially within the context of poverty. The results from Mexico's 2012 NHNS are in line with other studies demonstrating depression as a risk factor for abuse among the older adult population; this particular morbidity is highly prevalent among women in Mexico, resulting in vulnerability of abuse $[6,7,28,40,41]$.

This study also reflects the limitations posed by the NHNS. For example, the underreporting of violence perpetrated by a family member are framed by the consequences that the older adult that responded to the survey may face. We must also consider the very limited access to social programs that provide a solution and that intervene at the levels of determinants of social and family violence that impact this population group [9, 42]. Moreover, the cross-sectional analysis may have residual confounding effects due to variables not included, given that the NHNS used a general questionnaire as opposed to an instrument that was designed specifically to detect violence among older adults. Another 
limitation for the NSNH survey is that the category 'other types of aggression or abuse' does not discern or unpack its content.

\section{Conclusions}

The Mexico's 2012 National Health and Nutrition Survey allowed estimating the prevalence of violence towards older adults, as well as the associated factors.

Gender, and its implications in terms of education, income, social status, empowerment and self-esteem seem to explain the differences in the type, frequency and place of violence in older adults. In this regard, it is necessary to increase knowledge about the dynamics of the social determinants of violence, in particular the role of education and SES among men.

The complexity of the problem and gaps in the available information warrant further research that can explore this issue through the use of diverse methodologies and that include a consideration of the sociocultural, economic, and health system context. We also suggest a focus on the social determinants, both in the national and regional sphere, which takes into account the international agreements that exist to reduce the victimization of older adults and ensure their rights and dignity [42]. We highlight the need for public policies and community strategies aimed to abuse and violence prevention for older adults that are built on a culture of respect for human rights, and the participation of multiple stakeholders [23, 27] in the social process of enhancing the wellbeing of older people in the family and society.

\section{Competing interests}

The authors declare that they have no competing interests.

\section{Authors' contributions}

MGRG and MBDG conceived the study and secured authorization to use the survey database; SFH, MGRG and MBDG led study design and acquisition of data; SFH, DVOA and JDCG conducted the data analysis and interpretation; MGRG, MBD, SFH, DVOA, JDCG, AT and ALR all contributed to manuscript preparation and critical revisions. All authors read and approved the final manuscript.

\section{Authors' information}

MGRG is a researcher with the Center for Evaluation and Survey Research at Mexico's National Institute of Public Health. Her expertise is in vulnerable populations, violence and abuse in older adults in Mexico.

MBDG is a researcher at Mexico's National Institute of Public Health. Her research interests include social determinants of health and health services for vulnerable populations in Mexico and Colombia.

$\mathrm{SFH}$ is a researcher at the Center for Evaluation and Survey Research at Mexico's National Institute of Public Health. He has experience in epidemiological methods and statistical analysis for the National Health Survey on chronic diseases.

DVOA is a specialist in health education and culture. Her expertise is in women and community health, family and social networks health outcomes. She is a researcher at Mexico's National Institute of Public Health. JDCG is a doctoral student in Health Systems Sciences at Mexico's National Institute of Public Health. He is interested in the health of vulnerable populations, health behavior and built environment studies.

AT is an independent consultant for public health research and evaluation projects. Her expertise is in reproductive health, qualitative methods, and health services for vulnerable populations in Mexico and the U.S.
ALR is a researcher at the Center for International Health at the University of Bergen, Norway, and an associate researcher for the Center for the Study of Equity and Governance in Health Systems (CEGSS in Spanish), in Guatemala. Her research interests include equity and marginalized populations, social participation, the right to health and primary care.

\section{Author details}

${ }^{1}$ Instituo Nacional de Salud Pública, Cuernavaca, México. ${ }^{2}$ Centro de Estudios para la Equidad y Gobernanza en los Sistemas de Salud de Guatemala, and Center for International Health, Bergen University, Bergen, Norway.

${ }^{3}$ Independent consultant, Quintana Roo, Mexico.

Received: 27 November 2015 Accepted: 4 February 2016

Published online: 27 February 2016

References

1. World Health Organization. Global status report on violence prevention 2014. Geneva: World Health Organization; 2014. p. 292. Accessed at January 17, 2016, at: http://www.who.int/violence_injury_prevention/violence/ status report/2014/en/.

2. Krug E, Dahlberg L, Mercy J, Zwi A, Lozano R. Abuse of the elderly. In: Organización Panamericana de la Salud: World report on violence and health. Geneva: World Health Organization; 2002. p. 123-46. Accessed at May 4, 2015, at: http://www.who.int/violence_injury prevention/violence/status report/2014/en/.

3. Sethi D, Wood S, Mitis F, Bellis M, Penhale B, Iborra-Marmolejo I, et.al. (Eds.) European Report on preventing elder maltreatment. World Health Organization. 2011. http://www.euro.who.int/_data/assets/pdf_file/0010/ 144676/e95110.pdf. Accessed 20 Feb 2014.

4. Gaioli C, Rodrigues R. Occurrence of domestic elder abuse. Rev Lat Am Enfermagem. 2008;16(3):465-70. Accessed on October 09, 2015, at: http:// www.scielo.br/scielo.php?script=sci_arttext\&pid=S0104-11692008000300021 \&lng=en\&tlng=en.

5. Instituto Nacional de Estadística y Geografía, INEGI. Estadísticas a propósito del día internacional de las personas de edad (1 de octubre). 2014. http://www.inegi.org.mx/saladeprensa/aproposito/2014/adultos0.pdf. Accessed 23 Nov 2014.

6. Dyer CB, Pavlik VN, Murphy KP, Hyman DJ. The high prevalence of depression and dementia in elder abuse or neglect. J Am Geriatr Soc. 2000; 48(2):205-8.

7. Garre-Olmo J, Planas-Pujol X, López-Pousa S, Juvinyà D, Vilà A, Vilalta-Franch J. Prevalence and Risk Factors of Suspected Elder Abuse Subtypes in People Aged 75 and Older. J Am Geriatr Soc. 2009:57:815-22.

8. González V, González R. El maltrato en las personas mayores. In: Retos en la salud mental del siglo XXI. Maltrato. España: SEMERGEN; 2006

9. Cooper C, Selwood A, Livingston G. National Elder Abuse Incidence Study 1998 - Washington, DC; National Center on Elder Abuse. Age Ageing. 2008; 37:151-60.

10. Ribeiro-Espíndola C, Luis-Blay S. Prevalência de maus-tratos na terceira idade: revis o sistemática. Revista Saúde Pública. 2007;41(2):301-6.

11. DeLiema M, Gassoumis ZD, Homeier DC, Wilber KH. Determining Prevalence and Correlates of Elder Abuse Using Promotores: Low-Income Immigrant Latinos Report High Rates of Abuse and Neglect. J Am Geriatr Soc. 2012: 60(7):1333-9. doi:10.1111/j.1532-5415.2012.04025.x.

12. Ruelas-González MG, Salgado de Snyder N. Factores asociados con el autoreporte de maltrato en adultos mayores de México. Rev Chil Salud Pública. 2009;13(2):90-9.

13. Instituto Nacional de Estadística y Geografía, INEGI. Panorama de violencia contra las mujeres en Estados Unidos Mexicanos: ENDIREH 2011. In: Encuesta Nacional sobre la Dinámica de las Relaciones en los Hogares ENDIREH, 2011. México: Instituto Nacional de Estadística y Geografía; 2013. p. 151. Accessed 12 Oct 2014

14. Buvinic M, Morrison A, Orlando MB. Violencia, Crimen y Desarrollo Social en América Latina y el Caribe. 2012. http://www.redalyc.org/articulo. oa?id=11204309. Accessed 19 Feb 2015

15. Lathrop F. Protección jurídica de los personas mayores en Chile. Revista Chilena de Derecho. 2009:36(1):77-113.

16. Instituto Nacional de Estadística y Geografía, INEGI: Causas de defunción. Porcentaje de muertes violentas con respecto al total de defunciones por sexo y grupos quinquenales de edad de 2000 a 2013. http://www3.inegi.org.mx/sistemas/temas/default.aspx?s=est\&c=17484. Accessed 11 Jul 2015. 
17. Instituto Nacional de Salud Pública. ENSANUT, Encuesta Nacional de Salud y Nutrición. 2012. Accessed 25 January 2014. http://ensanut.insp.mx.

18. Romero-Martínez M, Shamah-Levy T, Franco-Nuñez A, Villalpando S, CuevasNasu L, Gutiérrez JP, et al. Encuesta Nacional de Salud y Nutrición 2012: diseño y cobertura. Salud Publica Mex. 2013;55 Suppl 2:332-40.

19. Gutiérrez JP. Clasificación socioeconómica de los hogares en la ENSANUT 2012. Salud Publica Mex. 2013;55 Suppl 2:341-6.

20. StataCorp LP. Statistics/Data Analysis. Stata College Station, Copyright 19852013. http://www.stata.com. Accessed 2 Feb 2014

21. Gómez-Ricárdez LA, Rodríguez-Abrego G, Krug Llamas E. Prevalencia y factores asociados a violencia familiar en personas mayores de Ocozocoautla (Chiapas, México). Rev Esp Geriatr Gerontol. 2007;42(1):27-34.

22. Giraldo-Rodriguez L, Rosas-Carrasco O, Mino-Leon D. Abuse in Mexican Older Adults with Long-Term Disability: National Prevalence and Associated Factors. Am Geriatr Soc. 2015:63:1594-600

23. Arriagada I. (Coord.). Familias y Políticas Públicas en América Latina. Una historia de desencuentros. Libros de la CEPAL, 96. Comisión Económica para América Latina y el Caribe (CEPAL) 2007. Santiago de Chile. p. 419. Accessed 4 Nov 2015. At http://www.cepal.org/es/publicaciones/2504familias-y-politicas-publicas-en-america-latina-una-historia-dedesencuentros

24. HelpAge International OHCHR. Public consultation on the human rights of older persons: submission of evidence by HelpAge International. 2013th ed. 2013. Accessed 4 Nov 2015. At: http://www.helpage.org/download/ $51 \mathrm{~b} 08 \mathrm{~d} 03544 \mathrm{e} 8$.

25. Lloyd-Sherlock P, Agrawal S, Minicuci N. Fear of crime and older people in low and middle-income countries. Ageing Soc. 2015, 1-26available on CJO2015. doi: 10.1017/S0144686X15000513.

26. Pillemer KA, Finkelhor $\mathrm{D}$. The prevalence of elder abuse: a random sample survey. Gerontologist. 1988;28:51-7.

27. Molina G, Guido L. (Co-Eds). Los nuevos retos que nos impone la convención Interamericana para prevenir, sancionar y erradicar la violencia contra la mujer. (Convención Belén do Pará). Serie Género y Salud Pública \# 3. Organización Panamericana de la Salud. Programa Mujer, Salud y Desarrollo. 1999. http://www.bvsde.paho.org/bvsacd/cd26/ gph3.pdf. Accessed 14 Jun 2014.

28. United Nations, UN. Neglect, Abuse and Violence against Older Women. Department of Economic and Social Affairs (UN-DESA). New Yor: Department of Economic and Social Affairs (UN-DESA); 2013. http://www. un.org/esa/socdev/documents/ageing/neglect-abuse-violence-olderwomen.pdf.

29. Cano SM, Garzón MO, Segura AM, Cardona D. Maltrato psicológico en los personas mayores del departamento de Antioquia, 2012. Rev Fac Nac Salud Pública. 2014;32 Suppl 1:99-106.

30. Campillo-Motilva R. Violencia con el anciano. Rev Cubana Med Gen Integr. 2002;18(4):293-5.

31. Docampo Santaló L, Barreto Lacaba R, Santana Serrano C. Comportamiento de la violencia intrafamiliar en el adulto mayor. AMC. 2009, 13(6) Accessed 12 Sep 2015. At: http://scielo.sld.cu/scielo.php?pid=S102502552009000600010\&script=sci_arttext.

32. Ribeiro-Ferreira M. Vejez, familia y política social. Revista Perspectivas Sociales. 2002;4(1):147-68.

33. Ríos-Oropesa D, Mena-Cantero A, Payarés-Martínez L, Deidre-Stwewick P. Comportamiento de los factores de riesgo en la violencia familiar contra el adulto mayor. Revista científico estudiantil de ciencias médicas de Cuba 2006. 224. Accessed 8 Sep 2015. At: http://www.16deabril.sld.cu/rev/224/ articulo3.html.

34. Pillemer K, Suitor JJ. Violence and violent feelings: What causes them among family caregivers? J Gerontol. 1992;47(4):S165-72.

35. Pillemer K. Elder abuse is caused by the deviance and dependence of abusive caregivers. Chapter 13. Current Controversies on Family Violence. 2005:207-220

36. Paveza GJ, Cohen D, Eisdorfer C, Freels S, Semla T, Ashford JW, et al. Severe family violence and Alzheimer's disease: Prevalence and risk factors. Gerontologist. 1992;32(4):493-7.

37. Lachs MS, Williams C, O'Brien S, Hurts L, Horowitz R. Risk factors for reported elder abuse and neglect: A nine-year observational cohort study. Gerontologist. 1997;37:469-74.

38. Medina-Mora ME, Borges-Guimaraes G, Lara C, Ramos-Lira L, Zambrano J, Fleiz-Bautista C. Prevalencia de sucesos violentos y de trastorno por estrés postraumático en la población mexicana. Salud Publica Mex. 2005;47:8-22.
39. Instituto Nacional de Estadística, Geografía e Informática. INEGI: Mujeres violentadas por su pareja en México, 2004. http://internet.contenidos.inegi.org.

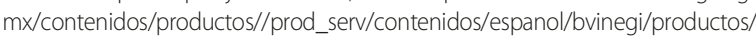
historicos/2104/702825450854/702825450854_1.pdf. Accessed 13 Jul 2015.

40. Belló M, Puentes-Rosas E, Medina-Mora ME, Lozano R. Prevalencia y diagnóstico de depresión en población adulta en México. Salud Publica Mex. 2005;47 Suppl 1:4-11.

41. Berenzon S, Lara MA, Robles R, Medina-Mora ME. Depresión: estado del conocimiento y la necesidad de políticas públicas y planes de acción en México. Salud Publica Mex. 2013;55:74-80.

42. Secretaría de Salud. 2006. Informe Nacional sobre la Violencia y Salud. México, DF: SSA. Gutiérrez-Robledo LM. Violencia y abuso contra las personas mayores. In: Secretaría de Salud: Informe Nacional sobre Violencia y Salud 2006. México. 2006. http://www.salud.gob.mx/unidades/cdi/ documentos/InformeNalsobreViolenciaySalud.pdf. Accessed 27 Oct 2014.

\section{Submit your next manuscript to BioMed Central and we will help you at every step:}

- We accept pre-submission inquiries

- Our selector tool helps you to find the most relevant journal

- We provide round the clock customer support

- Convenient online submission

- Thorough peer review

- Inclusion in PubMed and all major indexing services

- Maximum visibility for your research

Submit your manuscript at www.biomedcentral.com/submit
C Biomed Central 